Драгана Савин

dragana.nsseme@mail.ru
Прегледни рад

UDK 027.52:025.2(=811.161.2)(497.113)

655.3.066.1(=811.161.2)(497.113)“2013/2017“"

https://doi.org/10.18485/bibliotekar.2019.61.2.9

\title{
КОРИСНИЧКИ КЫИЖНИ ФОНД НА РУСИНСКОМ ЈЕЗИКУ У ГРАДСКОЈ БИБЛИОТЕЦИ У НОВОМ САДУ
}

Сажетак: У раду су приказани историјат настанка и најважнији моменти оснивања и рада Градске библиотеке у Новом Саду у оквиру које постоји књижни фонд на русинском језику Новинско-издавачке установе (НИУ) Руске слово. Издавачка продукција књига НИУ Руске слово у периоду 2013-2017, односно библиографија издавача Руске слово броји 41 наслов, у тиражима од 150 до 500 примерака по наслову. Градска библиотека у Новом Саду поседује само део продукције овог издавачког предузећа и то 12 наслова, који се већином налазе у Завичајној збирци. Приступ књигама у Завичајној збирци је омогућен свим члановима Градске библиотеке у Новом Саду, али је рад организован у форми читаонице.

Кључне речи: Градска библиотека, Нови Сад, Завичајна збирка, НИУ Руске слово, издаваштво, библиографија књига 2013-2017.

\section{Уводна разматрања}

Русини у Војводини имају развијену мрежу установа културе ${ }^{1}$, a русински језик је у службеној употреби를 администрацији ${ }^{3}$ Покрајине

1 Више о русинским установама културе видети у прегледном раду: Драгана Савин, „Русини у Војводини - установе културе”, MELISSA: Museums, Ethics, Library and Information Science, Studies, Archives 16/2 (2017): 113-136.

2 О службеној употреби русинског видети у: „Закон о заштити права и слобода националних мањина”, Службени іласник СРЈ бр. 11 (27. 2. 2002); „Закон о заштити права и слобода националних мањина”, Службени іласник РС бр. 72 (3. 9. 2009); „Закон о заштити права и слобода националних мањина", Службени іласник РС бр. 97 (6. 11. 2013). Последњи у низу је „Закон о изменама и допунама Закона о заштити права и слобода националних мањина”, Службени іласник РС бр. 47 (20. 6. 2018).

3 О положају русинског и других мањинских језика у Србији су писали и страни научници, 
Војводине. Једна од важнијих установа за Русине у Војводини је и Новинско-издавачка установа Руске слово са седиштем у Новом Саду, са својом издавачком делатношћу на русинском језику. Књиге штампане на русинском језику у издању Новинско-издавачке установе Руске слово ${ }^{4}$ налазе своје место у библиотечком фонду Градске библиотеке у Новом Саду.

Циљ овог истраживања ${ }^{5}$ је представљање издавачке продукције НИУ Руске слово кроз приказ урађене библиографије за период 2013-2017. и евидентирање присутности наслова, тј. књига из библиографије у фондовима Градске библиотеке у Новом Саду ради анализе доступности русинске књиге свим заинтересованим корисницима. Замишљено је да се провери да ли сваки наслов појединачно постоји на стању у Градској библиотеци у Новом Саду (и свим њеним огранцима) методом онлајн приступа преко сајта Библиотеке.

Наша очекивања су била да ће већина наслова, ако не и сви, постојати у неком од фондова Библиотеке а највише наслова смо очекивали на стању у Завичајној збирци. Исто тако, почетна претпоставка је била да ће најзаступљеније књиге у фонду Градске библиотеке бити књиге посвећене историјској тематици, културолошким проучавањима русинске традиције на овим просторима, научне монографије из језика (граматика, правопис, речници) и, напослетку, савремена књижевност.

\section{Градска библиотека у Новом Саду - библиотека јавног типа}

Градска библиотека у Новом Саду је библиотека јавног типа, припада мрежи јавних библиотека Србије, а уз библиотеку града Београда она је највећа јавна библиотека позајмног типа у земљи. Као јавна библиотека, Градска библиотека у Новом Саду се труди да испуни све дефинисане ви-

нпр: Д. А. Катунин, „Языковые права русинов, украинцев и других национальных меньшинств в законодательстве Республики Сербии”, Русин №1, 39 (2015): 229-238, Д. А. Катунин, „Русинский язык и языки других национальных меньшинств в законодательстве Воеводины. Статья 2", Русин № 1, 43 (2016): 271-284.

4 О оснивању прве новинске редакције с циљем штампања новина (недељника) на русинском језику видети: Дюра Латяк, Руснаци, том 1 (Нови Сад: Руске слово, 2017): 223-224. и Михајло Хорњак, „Бачко-сремски Русини (порекло, начин живота, положај и права, институције и организације)", у: Русини=Руснаци=Ruthenians: (1745-2005). 1, уредник Михајло Фејса (Нови Сад: Прометеј, 2007), 54-55.

5 Истраживање је урађено у склопу предиспитних активности на докторским студијама на Филолошком факултету у Београду под руководством проф. др Александре Вранеш. 
шеструке улоге које савремено библиотекарство поставља пред њу, тј. да обезбеди слободан, подједнак и неограничен приступ тековинама културе и цивилизације, до знања, идеја и информација ${ }^{6}$. А у вишенационалним срединама јавне библиотеке сматрају се и местима где се негује, чува и баштини мултикултурализам и интеркултурализам. Русински фонд у оквиру Библиотеке би требало да буде показатељ спремности и могућности једне мултикултуралне библиотеке „да своје фондове и ресурсе развија у складу са језичким и културним потребама друштва, да подједнако води рачуна о очувању свих културних наслеђа" .

Потребе и захтеви корисника фондова новосадске Градске библиотеке као мултикултуралне и библиотеке јавног типа су многоструке и сложене, због тога ћемо се у овом раду задржати само на једном њеном сегменту - на потребама русинске националне мањине и свих заинтересованих лица за приступ књигама на русинском језику.

\section{Оснивање библиотеке}

Градска библиотека у Новом Саду прославља 6. април 1958. као датум оснивања, када је Народни одбор општине Нови Сад - Секретаријат за просвету и културу донео одлуку о оснивању Народне библиотеке ${ }^{8}$ у Новом Саду, која од 1993. носи назив Градска библиотека9.

За развој новосадске Градске библиотеке важно је споменути неколико преломних момената, поред оснивања ту си и: 1961. година, када Библиотека Матице српске у договору са Скупштином општине Нови Сад уступа свој позајми фонд од 30.000 књига Народној библиотеци, уз фонд уступа се и стручни кадар, што омогућава убрзани развитак Народне библиотеке. Следећи важан догађај се десио 1. јануара 1962. када је Народни

6 Жељко Вучковић, Јавне библиотекеке и јавно знағе (Нови Сад: Библиотека Матице српске, 2003), 7.

7 Љиљана Башић, „Мултикултуралне библиотеке и заштита идентитета националних мањина", Гласник Нарояне библиоиекее Србије 14, 1 (2014/2015): 124.

8 Народна библиотека је настала припајањем и обједињавањем Српске читаонице новосадске (основане 23. септембра 1845. у Новом Саду), са осталим јавним књижницама и читаоницама на подручју Нови Сад (Анђелковић, Прилози за истиорију Граgске библиотиеке у Новом Саgy, 10).

9 Мирјана Анђелковић, Прилози за истиорију Граgске библиотеке у Новом Саgу: (1858-2008) (Нови Сад: Градска библиотека, 2009), 20. 
одбор општине Нови Сад доделио Библиотеци зграду10 у Дунавској 1, на трајно коришћење, и као установу културе ослободио обавеза плаћања закупа. ${ }^{11}$

\section{Огранци и фондови}

Библиотечку мрежу у Градској библиотеци чине огранци (њих 26). Tо су: 1. „Ђура Даничић”, Дунавска 1 и 2. Дечје одељење на истој адреси, 3. „Стеван Сремац”, 4. „Коста Трифковић”, 5. „Владимир Назор” (Петроварадин), 6. „Вељко Петровић”, 7. „Петефи Шандор”, 8. „Михал Бабинка” (Кисач), 9. „Јован Јовановић Змај” (Футог) 10. „Јован Јовановић Змај” (Сремска Каменица), 11. „Ђорђе Арацкић” (Лединци), 12. „Никола Тесла” (Степановћево), 13. „Петар Кочић” (Ветерник), 14. „Ади Ендре” (Будисава), 15. „Милица Стојадиновић Српкиња” (Буковац), 16. „Лаза Костић” (Ковиљ), 17. „Бранко Радичевић” (Сремски Карловци), 18. „Жарко Зрењанин Уча”, 19. Библиобус - покретна библиотека (1973-1983), 20. „Иво Андрић” (Руменка), 21. „Данило Киш” (основан 1976. кад је носио назив „Вера Павловић”), 22. „Бура Јакшић” (Каћ), 23. „7. јули” (1978-1997), 24. „Тоша Трифунов” (Бегеч), 25. Посебни фондови - „Б” фонд (фонд стручне литературе из области библиотекарства), British Council - Фонд британске књиге и 26. Завичајна збирка „Арса Пајевић” (Анђелковић, 2009: 38-39).

Према речима Мирјане Анђелковић страни фонд је у периоду оснивања библиотеке био значајан део фонда, касније су се стране књиге слабо принављале, али на језицима националних мањина куповане су сваке године у мањем или већем броју. Те књиге су пристизале од издавача Magyar szó и Руске слово, али после 1985. издавачка делатност мањинских кућа слаби, па се у Библиотеци ове књиге слабо принављају. С друге стране, временом оне постају неактуелне, али и физички пропадају ${ }^{12}$. Међутим, у истом раду на страни 393 постоји преглед приновљених књига на страним језицима и језицима мањина од 1965. до 2008. у коме се види да се књиге на русинском језику изузетно слабо набављају, тако да годинама нема ниједне нове књиге, а само у неким годинама фонд се проширивао, најберићетније

\footnotetext{
10 Зграда је била породично власништво Арсе Пајевића, познатог књижара, штампара, издавача, писца, културног радника и великог добротвора.

11 Анђелковић, Прилози за истиорију Граяске библиоиеке у Новом Саgy, 11.

12 Анђелковић, Прилози за истиорију Граяске библиоиеке у Новом Саgу, 50.
} 
су биле 1983. са приновљених 90 књига на русинском и 2008. са 137 наслова, године које се још помињу су 1985. са 15, а 1986, 1988, 1989, 1997. и 2006. су све са испод 10 нових наслова по години.

\section{Завичајна збирка}

Градска библиотека је од првих дана имала Завичајну збирку коју ствара издвајањем књига из постојећих фондова куповином ${ }^{13}$ и поклонима ${ }^{14}$. Збирка је неуређена све до 1975. када добија библиотекара Данку Бајић и када се доносе Основне концейције оріанизовавюа и раgа у Завичајној збириз ${ }^{15}$.

Завичајна збирка ${ }^{16}$ 1990. добија име „Арса Пајевић” и сели се у недовољно искоришћени огранак у Улици цара Душана, где се оформљује у потпуности и где постоје услови и за постојање читаонице, тако постаје могућ и истраживачки рад свим заинтересованим грађанима ${ }^{17}$. Оно што се, нажалост, не помиње у овој монографији је да, иако сви чланови Градске библиотеке имају приступ овој Збирци, постоје и две ограничавајуће околности: прва је да се књиге не могу износити из зграде Библиотеке (позајмљивати на читање), а друга је радно време које је радним даном до 15.00 сати, што отежава приступ књигама одређеним групама корисника (нпр. запослени, деца предшколског узраста).

13 Начин набавке је различит: куповина има предност у односу на куповину књига за друге фондове), поклони (сваки поклон се прво упућује у Завичајну збирку), размена са другим установама, обавезан примерак штампара и издавача (Анђелковић, Прилози за истиорију Граяске библиоиекке у Новом Саgу, 71).

14 Многе установе поклањају књиге и грађу Градској библиотеци: Библиотека Матице српске 1999. поклања овој збирци 2.416 библиографских јединица. Удружење архитеката поклања грађу из своје архиве. Поклањали су и Удружење Срба у Мађарској, Музеј града Новог Сада, Архив Војводине, Галерија Рајка Мамузића, Српска читаоница из Ирига, АМБ „Графика” (Анђелковић, Прилози за истиорију Граяске библиотеке у Новом Саgу, 79).

15 Анђелковић, Прилози за истиорију Граяске библиоиеке у Новом Саgy, 41.

16 Напоменули бисмо овом приликом и критеријуме за материјал који улази у Завичајну збирку у најважнијим цртама: завичај чини гео-физичка, политичка и административна целина у данашњем смислу речи, тј. Нови Сад, Сремски Карловци, Сремска Каменица, Петроварадин, Лединци, Буковац, Ветерник (...); језик штампања није ничим ограничен, али се посебна пажња посвећује материјалу на: српском, мађарском, словачком, русинском и румунском језику; завичајни материјал представљају штампане ствари ако је аутор рођен на завичајној територији, ако је живео на територији или био везан духовно за њу, садржај књига говори о њој и издавач је са дате територије (Анђелковић, Прилози за иситорију Граяске библиоиеке у Новом Саgу, 69).

17 Анђелковић, Прилози за исиорију Граяске библиоиекке у Новом Саgy, 77-78. 


\section{Издавачка делатност НИУ Руске слово - Библиографија књига у периоду 2013-2017}

Циљ истраживања овог рада је презентовање стручној и широј јавности издавачке продукције књига НИУ Руске слове у периоду 2013-2017, односно анализа урађене библиографије књига издавача Руске слово. У току израде библиографије поставили смо задатке: сачинити хронолошки преглед публикованих књига и пропратити доступност у огранцима и фондовима Градске библиотеке у Новом Саду. Током организовања библиографске грађе придржавали смо се следећих правила у раду: према начину библиографског описа библиографија је специјална, према критеријуму времена које обухвата је ретроспективна. По карактеру и намени библиографија је исрцпна (потпуна). Приликом организације грађе, примарни критеријум је био година издања, потом редослед публиковања по подацима издавача, као и регистар аутора. Библиографија садржи 41 јединицу, поштовано је писмо публикације, приликом њене израде коришћен је Кобис онлајн информациони систем Библиотеке Матице српске, Библиографија книга у Војводини ${ }^{18}$, као и новија библиотечка издања ${ }^{19}$. После сваке библиографске јединице смо забележили да ли се књига налази у корисничком фонду Градске библиотеке у Новом Саду и у којем огранку, или књиге нема у фондовима библиотеке. Ове податке смо добили од дежурног библиотекара у огранку „Ђура Даничић” у центру града 3. маја 2018, који нам је проверио сваки наслов понаособ, будући да је тих дана била онемогућена онлајн провера са дистанце због мењања библиотечког софтвера. Регистар аутора садржи 47 јединица у којима су бележени следећи подаци: презиме и име аутора, година рођења (и смрти), врста ауторства (аутор текста, аутор илустрације, аутор поговора, уредник, преводилац, рецензент, приређивач, аутор фотографије) и редни број у библиографији.

Новинско-издавачка установа Руске слово је у периоду од 2013. до 2017. године публиковала 41 наслов у тиражима од 150 до 500 примера-

18 Селимир Радуловић, гл. уредник, Библиоірафија кюиі̄a у Војвоgини 2013 (Нови Сад: Библиотека Матице српске, 2015). Селимир Радуловић, гл. Уредник, Библиоірафија књиїа y Војвоgини 2014 (Нови Сад: Библиотека Матице српске, 2016). Селимир Радуловић, гл. Уредник, Библиоірафија књиїа у Војвоgини 2015 (Нови Сад: Библиотека Матице српске, 2017).

19 Бојана Грујић, Библиоірафија изgана Граяске библиоиеке у Новом Саgу: 1971-2015 (Нови Сад: Градска библиотека, 2017); Љ. Косијер, Библиоірафија свезака за истиорију Нової Саgа (бројеви 11-16). Семинарски рад. (Сомбор: Педагошки факултет, 2016). 
ка. Од поменуте 41 књиге, само њих 12 се налази у фондовима Градске библиотеке у Новом Саду. То су следеће књиге, поређане по сачињеној библиографији (редни број у библиографији, наслов, аутор, година издања, фонд у коме се налази књига): 1. Чом чомка нє ма уха? : писнї за дзеци / Ана Тамаш (2013) налази се у Завичајној збирци, 2. Потаргани червени цверни : приповедки / Саша Сабадош (2013) налази се у Завичајној збирци, 4. Чом ше качка з воду мачка : приповедки и писньочки за мали дзеци / Юлиян Пап (2013) налази се у Завичајној збирци, 5. Лядова трава : (нови и стари писнї) / Владимир Кочиш (2013) у Завичајној збирци, 6. Жвирки у азбуки : руска азбука / Мелания Римар (2013) налази се у Одељењу за страну књигу, 7. Шнїюци гвизду Геутераниї : геутеранистично-белетристични венєц. 1. белетристични том, За горами : роман / Владимир Кирда Болхорвес (2013) у Завичајној збирци, 8. Зайда за мирни сон : (писнї) / Штефан Гудак (2013) у Завичајној збирци, 20. Галов : критики, огляди, есеї / Ирина Гарди-Ковачевич (2015) у Завичајној збирци, 30. Шантовки : есеї / Микола Шанта (2016) у Завичајној збирци, 36. Конь зоз чудесней ноци : вибрани писнї / Владимир Гарянски (2017) налази се у огранку „Данило Киш“, 40. Инисур рика княза : фантастични роман за младих / Себастиян Няради (2017) у Завичајној збирци, 41. Дармоєди : писнї / Саша Сабадош (2017) у Завичајној збирци. Као што се види, од дванаест књига, њих десет се налази у Завичајној збирци, једна у фонду стране књиге и једна у огранку „Данило Киш“. Из списка наслова који се налазе у фондовима Градске библиотеке примећујемо да је највише њих из 2013. године, 7 од 12, потом 1 из 2015, 1 из 2016. и 3 из 2017. Што се тиче тематике, насупрот очекивањима да ће највише наслова бити из историје, културологије и језика, највише наслова је посвећено дечијој књижевности и оригиналним делима русинских аутора млађе и средње генерације за децу (песме за децу, приповетке, успаванке, фантастичан роман за младе).

На основу ових података може се закључити да се фонд књига на русинском језику изузетно слабо принавља, да је највише књига из 2013. године, док нема ниједне из 2014, једна је из 2015. и једна из 2016. и свега три из 2017. Наслови који се налазе у фондовима Библиотеке већином се - њих 10 од 12 - чувају у Завичајној збирци која јесте доступна свим члановима Библиотеке, али је њен рад организован у форми читаонице без могућности позајмљивања књига, као и са ограниченим радним временом до 15.00 сати, што умногоме органичава доступност књига на русинском језику већем броју заинтересованих корисника.

У вишенационалним срединама, као и у градовима с богатом историјом, традицијом и културом - какав је и Нови Сад - значај и важност 
постојања и развијања рада јавне мултикултуралне библиотеке, као што је Градске библиотека у Новом Саду, огроман је. Поред обученог, школованог и вредног библиотекарског кадра за добар рад и пружање услуга што већем и ширем кругу корисника потребан је и богат и разноврстан књижни фонд. Библиотекари у Градској библиотеци у Новом Саду су школовани, обучени, изузетно вредни и предусретљиви, али су фондови, поготово у анализираном аспекту који се односи на издања на русинском језику издавача Руске слово - врло оскудни. Узрок те појаве бисмо приписали ограниченим материјалним средствима за обнављање/куповину књига, уз логичну претпоставку да се прво принављају најновији наслови и најпопуларнији за најширу читалачку публику а тек потом на страном језику и језицима националних мањина. С друге стране, остаје нам само да се надамо да ће издавачи са подручја Новог Сада почети да достављају обавезни примерак јавној библиотеци града.

\section{Закључак}

На основу изнетих података, можемо закључити да Градска библиотека у Новом Саду чини све да испуни задатке и улоге који се стављају пред савремену мултикултуралну библиотеку. Нажалост, Градска библиотека у Новом Саду не успева у томе у потпуности. Књижни фонд на русинском језику је недовољно богат и разноврстан, а доступност издањима је умногоме лимитирана радним временом и организацијом рада у форми читаонице. Позитивна чињеница јесте да се у Библиотеци посебна пажња поклања избору књига намењених деци и младима на русинском језику, али је нејасно зашто се ти наслови чувају у слабо доступном фонду Завичајне збирке.

Наша скромна жеља би била да овај рад посветимо и уједно се захвалимо на несебичној помоћи преданим библиотекарима Градске библиотеке у Новом Саду, али и да позовемо и подсетимо издаваче са територије Новог Сада, поготово оне који издају књиге на језицима националних мањина, да донирају примерке Градској библиотеци, јер на тај начин не помажу само суграђанима него и сами они, као и њихова издања, постају јавности „видљивији”, препознатљивији и доступнији. 


\section{Literatura:}

1. Anđelković, Mirjana. Prilozi za istoriju Gradske biblioteke u Novom Sadu: (18582008). Novi Sad: Gradska biblioteka, 2009. (na ćirilici)

2. Bašić, Ljiljana. „Multikulturalne biblioteke i zaštita identiteta nacionalnih manjina”. Glasnik Narodne biblioteke Srbije 14, 1 (2014/2015): 121-129. (na ćirilici)

3. Grujić, Bojana. Bibliografija izdanja Gradske biblioteke u Novom Sadu (1971-2015). Novi Sad: Gradska biblioteka, 2017. (na ćirilici)

4. Hornjak, Mihajlo. „Bačko-sremski Rusini (poreklo, način života, položaj i prava, institucije i organizacije)”. U: Rusini=Rusnaci=Ruthenians: (1745-2005): 1, urednik Mihajlo Fejsa, 23-73. Novi Sad: Prometej, 2007. (na ćirilici)

5. Kosijer, Lj. Bibliografija svezaka za istoriju Novog Sada (brojevi 11-16). Seminarski rad. Sombor: Pedagoški fakultet, 2016. (na ćirilici)

6. Radulović, Selimir, gl. urednik. Bibliografija knjiga u Vojvodini 2013. Novi Sad: Biblioteka Matice srpske 2015. (na ćirilici)

7. Radulović, Selimir, gl. urednik. Bibliografija knjiga u Vojvodini 2014. Novi Sad: Biblioteka Matice srpske 2016. (na ćirilici)

8. Radulović, Selimir, gl. urednik. Bibliografija knjiga u Vojvodini 2015. Novi Sad: Biblioteka Matice srpske 2017. (na ćirilici)

9. Savin, Dragana. „Rusini u Vojvodini - ustanove kulture”. MELISSA : Museums, Ethics, Library and Information Science, Studies, Archives 16/2 (2017): 113-136.

10. Vučković, Željko. Javne biblioteke i javno znanje. Novi Sad: Biblioteka Matice srpske, 2003. (na ćirilici)

11. „Zakon o izmenama i dopunama Zakona o zaštiti prava i sloboda nacionalnih manjina”. Službeni glasnik RS br. 47 (20. 6. 2018). (na ćirilici)

12. „Zakon o zaštiti prava i sloboda nacionalnih manjina”. Službeni glasnik SRJ br. 11 (27. 2. 2002). (na ćirilici)

13. „Zakon o zaštiti prava i sloboda nacionalnih manjina”. Službeni glasnik RS br. 72 (3. 9. 2009). (na ćirilici)

14. „Zakon o zaštiti prava i sloboda nacionalnih manjina”. Službeni glasnik RS br. 97 (6. 11. 2013). (na ćirilici)

15. Катунин, Д. А. „Языковые права русинов, украинцев и других национальных меньшинств в законодательстве Республики Сербии”. Русин, №1 (39) (2015): 229-238.

16. Катунин, Д. А. „Русинский язык и языки других национальных меньшинств в законодательстве Воеводины. Статья 2”. Русин, № 1 (43) (2016): 271-284.

17. Латяк, Дюра. Руснаци, том 1. Нови Сад: Руске слово, 2017. 


\title{
Dragana Savin
}

dragana.nsseme@mail.ru

\section{COLLECTION OF BOOKS IN RUSYN LANGUAGE AT THE NOVI SAD CITY LIBRARY}

\begin{abstract}
This paper presents the history and the most important moments related to the establishment of the Novi Sad City Library which also houses a collection of books in Rusyn language published by the Newspaper Publishing Institution Ruske Slovo. The subject of this paper is the publishing activity of the Newspaper Publishing Institution Ruske Slovo in the period 2013-2017. The bibliography of books contains 41 titles, with the circulation of 150 to 500 copies per title. The Novi Sad City Library holds only a part of the production of this publishing company, 12 titles, mainly belonging to the Local Collection. All members of the Novi Sad City Library have access to the books in the Local Collection, but they can be used only in a reading room with limited working hours.
\end{abstract}

Keywords: City Library, Novi Sad, Local Collection, Newspaper Publishing Institution Ruske Slovo, publishing, bibliography 2013-2017.

Примљено: 13. децембра 2018.

Исправке: 3. априла 2019.

Прихваћено: 21. маја 2019. 